\title{
Escenarios de conflictividad histórica: la «masacre de Trelew» desde el cine argentino
}

Andrea Bolcatto

UNL / UNER

\section{Resumen}

Dentro de las narrativas audiovisuales, el cine es una de las fuentes que nos posibilitan el acercamiento a la construcción de sentido y comprensión del pasado histórico y a las formas de representación de los procesos sociales, tanto en su estilo documental como el denominado «argumental» $\mathrm{o}$ «ficcional». En este trabajo presentamos reflexiones en torno a la conflictividad y dinámica de los momentos revolucionarios, particularmente la década del '60-'7o desde un hito especialmente valioso como el caso de la denominada «masacre de Trelew» en Argentina. El análisis lo realizamos desde la apreciación de las distintas formas de narrativas audiovisuales provistas por las películas Ni olvido ni perdón (Raymundo Gleyzer, 1973) y Trelew. Historia de una fuga (Mariana Arruti, 2004). Ingresar desde las narrativas audiovisuales nos exige poner la mirada en lugares del discurso histórico y político quizás menos frecuentados, no para señalar co-

Palabras clave:

narrativas audiovisuales, conflictividad revolucionaria, memorias. 
rrespondencias o ejemplificaciones entre los basamentos teóricos y las producciones del cine sino para explorar en este último cristalizaciones de las definiciones, contradicciones y tensiones que sobre dichos acontecimientos conflictivos pudieran expresarse. Las problemáticas y articulaciones de diferentes coyunturas históricas y culturales se exponen y articulan en las producciones cinematográficas de muy distintos modos y sentidos.

\section{Abstract}

Within the audiovisual narratives, the cinema is one of the sources that we allow the approach to the construction of meaning and understanding of the historical past and the forms of representation of social processes, both in its documentary style or «fictional».

In this work we present reflections on the revolutionary unrest of the '60-'70 from a milestone especially valuable as the case of the so-called "massacre of Trelew» in Argentina.

The analysis was performed from the forms of audiovisual narratives provided by the films $\mathrm{Ni}$ olvido $\mathrm{ni}$ Perdon (Raymundo Gleyzer, 1973) and Trelew. Historia de una fuga (Mariana Arruti, 2004).

Enter from the audiovisual narratives requires us to look in places of historical and political discourse perhaps less frequented, not to draw correspondences or exemplifications between the theoretical foundations and the productions of the film, but to explore in the latter, crystallizations of definitions, contradictions and tensions that on these conflicting developments could be expressed.

The problematics of different cultural and historical circumstances are exposed and articulate in the cinematographic productions of very different modes and senses.

\section{Keywords:}

audiovisual narratives, revolutionary unrest, memories. 